University of Rhode Island

DigitalCommons@URI

Open Access Master's Theses

1988

\title{
Joyce and the Dialogical: Literary Carnivalization in Ulysses
}

Stephanie A. Almagno

University of Rhode Island

Follow this and additional works at: https://digitalcommons.uri.edu/theses

\section{Recommended Citation}

Almagno, Stephanie A., "Joyce and the Dialogical: Literary Carnivalization in Ulysses" (1988). Open Access Master's Theses. Paper 1089.

https://digitalcommons.uri.edu/theses/1089

This Thesis is brought to you for free and open access by DigitalCommons@URI. It has been accepted for inclusion in Open Access Master's Theses by an authorized administrator of DigitalCommons@URI. For more information, please contact digitalcommons-group@uri.edu. 


\author{
JOYCE AND THE DIALOGICAL: \\ LITERARY CARNIVALIZATION IN ULYSSES \\ BY \\ STEPHANIE A. AIMAGNO
}

A THESIS SUBMITTTED IN PARTIAL FULFILLMENT OF THE REQUIREMENTS FOR THE DEGREE OF MASTER OF ARTS

IN

ENGLISH

UNIVERSITY OF RHODE ISLAND

1988 


\section{MASTER OF ARTS THESIS \\ OF}

STEPHANIE A. ALMAGNO

\section{APPROVED:}

Thesis Committee

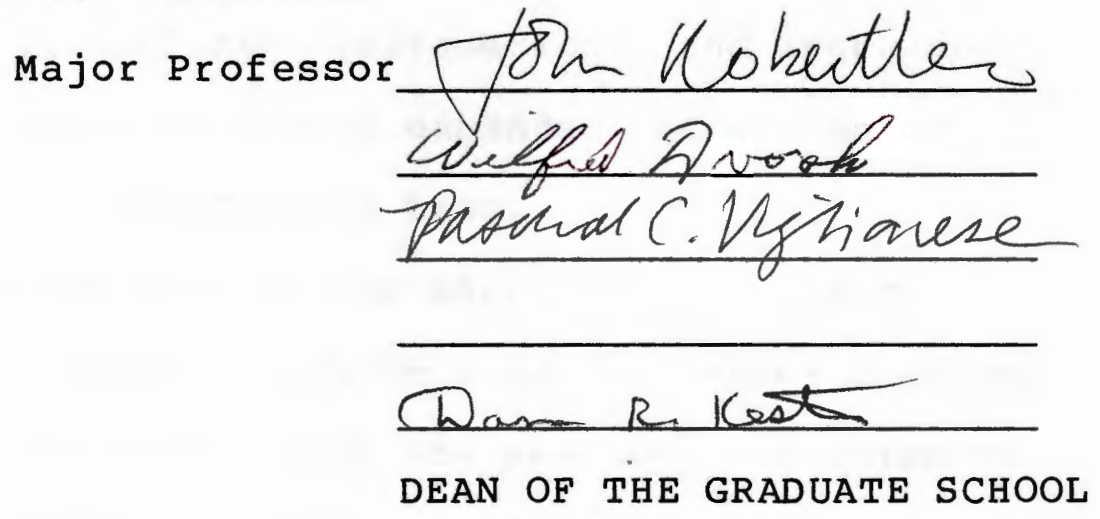

UNIVERSITY OF RHODE ISLAND

1988 


\section{THESIS ABSTRACT}

With the critical writings of Mikhail Bakhtin as a guide, this thesis attempts to not only illuminate a Joycean text, Ulysses, but also to examine the complexity of what constitutes textuality.

This essay will resituate Ulysses and will explicate and analyze passages which have as yet to be examined as integral parts of a literary puzzle. The cohesive element of the essay utilizes Bakhtin's categories of literary carnivalization, Parody, Reversals, Dualisms, Profanations, and Grotesque Realism, as they aid an expanded discussion of Ulysses as a dialogical text.

In order to indicate where/how my reading was going to expand the guidelines for future readings. I had to establish what the previous criticism was and in order to illustrate its limitations, I offer Bakhtin as a new model for Joycean literary criticism. Tthe result is an explication of a body of work engaged in dialogue with itself, with the society that created it, and is an examination of a text's possible fictive limitations. 


\section{ACKNOWLEDGEMENT}

I extend my sincere appreciation

to all the people who have supported

me during this entire project.

A special thank you is extended to

Prof. John R. Leo

Prof. Wilfred Dvorak

Prof. Pat Viglionese

Prof. Ira Kuhn

for surviving all the short notice

deadlines; your help was appreciated more than you know.

To John--snort!--I could not have done this without you. 


\section{TABLE OF CONTENTS}

Part 1: Joyce and the Dialogical

I. Introduction: Resituating Ulysses...........

II. Introduction to Textual Analysis.........9

Part 2: Textual Analysis.................

I. Elements of Literary Carnivalization

1. Parody.....................16

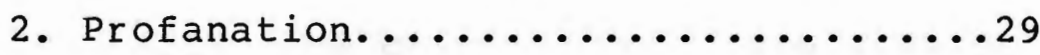

3. Dualisms..........................

4. Reversals........................

5. Grotesque Realism.............43

II. Conclusion...................... 54

Part 3: Bibliography.................... 56 
Part 1: Joyce and the Dialogical

I. Introduction: Resituating Ulysses: The Dialogical and the Critical Heritage of Ulysses.

The main focus of this study is an examination of the carnivalesque in James Joyce's Ulysses. I will follow Mikhail Bakhtin's subdivision of literary carnivalization focusing on five components--Parody, Profanations, Reversals, Dualisms, and Grotesque Realism--demonstrating how and where these appear in Ulysses. The five subdivisions lend themselves to the analysis and discussion through various scenes from the text and offer a more sophisticated method by which to read the text.

Until recently, the criticism of Joyce's major fiction has tended to focus on characterizations, aesthetic uses of language, or themes and ideas present in one or all of his works. However, Joyce's legacy is not his placement of images and symbolic patterns throughout his works, but rather, the form of the novel itself. For the most part, Joycean scholarship has constituted source studies (Moseley's Joyce and the Bible), parallels (Noon's Joyce and Aquinas, Schutte's Joyce and 
Shakespeare, Cross' Flaubert and Joyce), and historicist reductions of the literary to the historical (Goldberg's The Classical Temper). These works have tended to be formalist in nature, focusing on aspects of the text as isolated linguistic events or reflections of historical matter. I will examine Ulysses, with the help of Russian formalism, and illustrate how the text is already a social function and how society is inflected by the formal. This study will demonstrate new methods of reading/conceiving of a text, and subsequently shed new light on Joyce's achievements.

An early twentieth century Russian theorist, Mikhail Bakhtin, whose writings have been increasingly influential for literary historicism and criticism since the late 1960's, wrote extensively on the work of Fydor Dostoevsky and François Rabelais. Bakhtin's detailed analysis of literary structure illuminates reasons for my interest in Joyce. His explication of Dostoevsky's work as "polyphonic" texts, while concentrating on structural apparatuses such as the carnivalization of literature, offer a basis with which to examine the ability of literary forms to affect and to highlight the language and hierarchy of a society. Moreover, Bakhtin invites us to reconceptualize the "novel," no longer viewing it as a 2 
static monologic text, one with a single authorial discourse manipulating action and thought as if it is the sole discourse of an individual. Rather, Bakhtin invites us to view novel form as dialogic, possessing an "intertextual dimension" (Todorov, 1984, x) and thus offering limitless possibilities for representations of people and their culture. In Bakhtin's view this layering--or polyphony--is developed through dialogic components in modes of communication including dialogue, slang, gossip, narration. Polyphony is not found exclusively in oral communication but also in print, where it may represent social dialogue constructed with knowledge of the codes guiding the creation of the images within a text. Ulysses in particular exemplifies the multitude of forces created by and existing within a text, although these elements may be found in The Dubliners and A Portrait of the Artist, and continued through Finnegans Wake.

In order to stitch together the various elements in Ulysses and Joycean literary criticism, three points not usually included in traditional criticism must be defined.

1. Polyphony: polyvocality, dialogue, incorporating Joyce, his characters, and his readers through the development and use of literary carnivalization. 
2. Carnivalization: literary carnivalization as a structural device divided into five components illuminating Ulysses as a chronicle of power structures and of the dialogical in society.

3. The Body: a polymorphous construction representing various layers of communication.

The interaction of these three dialogical perspectives acknowledges the solid foundation grounding Ulysses as a text, challenging statements like "Ulysses is an attempted synthesis, foredoomed to failure by the very conditions it assumes." (Levin, 19) Rather, the fabric of the text is woven through a close analysis of literary carnivalization, as it fosters polyphony, and as it establishes the body as a valid vehicle for representing what has not been discussed, let alone incorporated into a literary text. Moreover, the three points indicate the existence of the "other", the destabilization of traditional representations of reality. The "other" validates the dialogic principles of polyphony and intertextuality as it destroys the monologic notion of what constitutes a text. For example, one of the earliest critical commentaries about Ulysses introduced and upheld the intertextual--the multidimensional--representations of society possible in a single text. 
In 1933, when Ulysses was tried for obscenity, Judge Woolsey wrote the decision freeing the text from any preconceived value judgments concerning the propriety of printed images.

In writing Ulysses, Joyce sought to make a serious experiment in a new, if not wholly novel, literary genre. He takes persons of the lower middle class living in Dublin in 1904 and seeks not only to describe what they did on a certain day early in June of that year as they went about the City bent on their usual occupations, but also to tell what many of them thought about the while.

Woolsey's focus is the obvious: the people and their lower middle class backgrounds, the fact that only one single day is represented in the entire text, and that Joyce works so closely with his characters' thoughts, and likening Joyce's work to "a multiple exposure on a cinema film,"l exemplifies what Bakhtin calls a polyphonous text. Woolsey identifies the various layers within Ulysses, which were both repressed and considered to be obscene. The simultaneous incorporation of individual elements of society, highlighted by Woolsey, establishes the foundation for a multiplicity of points-of-view 
incorporating caricatures of "types" of people found in any city. Joyce's characters become representations for the cumulative social history of a community and thus these codes internalized aid their self-definition.

Personal vision and interpretation offer nearly limitless commentary on a solitary occurrence. subsequently, the text is layered with personalities and individual accounts of one day in Dublin, assembled on top and adjacent to each other, achieving a collage-effect within the confines of the text. The primary example of this unique angle of vision dominates the Circe (Nighttown) episode. The intermingling of perceptions of reality, occurring in a central location, also describes the foundations of carnivalization, as I discuss below.

This layering of Joyce's work is demonstrated best through a close structural reading, examining the larger underlying structures of the text, and its dialogical components as indicațive of multidimensional Dublin life itself. Although the Odyssey parallel focuses on the structure of the text, other technical and structural elements are evident and need analysis in order to determine how Joyce recreates not only the nuances of a pulsating society, but also the art of writing novels which continually recreate audience expectations of fiction. 
Traditionally the Odyssey/Ulysses parallel has been an effective agent of literary analysis; however, the greater structure of Joyce's text is readily illustrated by its incorporation of carnivalistic principles. The definition of social carnivalization should be examined in order to best illustrate its transformation into literary carnivalization.

Carnival is a pageant without footlights and without a division into performers and spectators. In carnival everyone is an active participant, everyone communes in the carnival act. Carnival is not contemplated and, strictly speaking, not performed; its participants live in it, they live by its laws as long as those laws are in effect; that is, they live in a carnivalistic life. Because carnivalistic life is life drawn out of its usual rut, it is to some extent "life turned inside out," "the reverse side of the world" ("monde a l'envers"). (Bakhtin, 1984 122)

The result of social carnivalization in a literary text is as follows: 
Carnivalization made possible the creation of the open structure of the great dialogue, and permitted social interaction between people to be carried over into the higher sphere of the spirit and the intellect, which earlier had always been primarily the sphere of a single and unified monologic consciousness . . Carnival forms, transposed into the language of literature, became a powerful means for comprehending life in art . . Many essential sides of life, or more precisely its layers - . can be located, comprehended, and expressed only with the help of this language. (Bakhtin, $1984,157,177)$

The carnivalization of literature, the integration of dialogical components within a textual representation of society, reached its.height, according to Bakhtin, in such works as Cervantes's Don Quixote, Rabelais's Gargantua and Pantagruel, and Ben Jonson's Volpone. With the unique characteristics of the carnivalistic novel, even at a cursory glance it is evident that Joyce was aware and influenced by the carnivalistic tradition in literature because language (and the text) is already embedded with the social--literary carnivalization comes from the social 
as social forms are inscribed in language and in literature.

Ulysses is a prime subject for the illustration of polyphony in fiction because the discourses, the many voices, and the examination and use of the history of language found in a carnivalistic text signal that the construction of the text exceeds any formalist description. The text invites us to evaluate its construction through the subtle transformations of its narrative through the staging of dialogue, juxtaposition, and apposition. No longer is narration purely for the transmission of information, but rather, it becomes a part of the story-telling, an integral part of the story itself. Society defines itself through its own language, and consequently, story-telling reflects that society in which it was created.

II. Introduction to Textual Analysis.

Literary carnivalization within Ulysses invites new perceptions and definitions of "fiction," forcing a break with traditional fictional framework: beginning, middle, and end with a plot requiring causality, connection, and resolution. Joyce requires a new audience not only 
willing to participate with his characters, but also to redefine the limitations of text: to represent society as well as the text's ability to make meaning.

Literary carnivalization as a structural apparatus, presents a framework with which to understand the characteristics and results of discourse within a text. Carnivalization demands the examination of the cultural determinants and the dialogic function of language because carnivalization discloses a community's rules, how the community makes meaning. Language as culturally determined is particularly important for an Irish writer dominated by English control and definition; consequently, Joyce's language is already dialogic, embedded in a cultural discourse. Moreover, definition of a structural framework not aligned with the dominant ideological culture allows the reader to view more clearly that society and the layers of discourse opposed to the dominant, monologic view. What develops in contrast to monologic, authorial control is a multidimensional discourse mimicking the actual discourse of a society. However, writing and speaking, both narrational acts, are in turn embedded within and largely constructed by a culture, forming the "social bond" itself. As Jean-François Lyotard writes: 
Narratives, as we have seen, determine criteria of competence and/or illustrate how they are to be applied. They thus define what has the right to be said and done in the culture in question, and since they are themselves a part of that culture, they are legitimated by the simple fact that they do what they do. (Lyotard, $1984,23)$

Narratives are socially pre-conditioned by the structure in which they exist. In Ulysses, Joyce not only writes a work of fiction, but illustrates the layers of control which condition the act of discourse itself. Polyphony allows Joyce to examine the layers, the strategies, of social indoctrination.

The reader of Ulysses is aware of the staunch Irish Catholic culture of Dublin. Leopold Bloom is Jewish in a very Catholic city. Without editorially, or even explicitly, describing the pressure of knowing that one is inherently different from the mass population, Joyce's narration of Bloom visiting a butcher shop stages the social constraints, the embarrassment and racial self-consciousness, for a particular ethnic population.

He halted before Dlugacz's window, staring at the hanks of sausages, polonies, black 
and white. - He withdrew his gaze after an instant. No: better not: another time. $(58,60)$

Here, Bloom is deciding whether to tell Dlugacz that he is Jewish. He does not admit to publicly here, rather, he decides to wait until later; although he does take home the kidney. Instantly juxtaposed with Bloom's "sin" against his social rules is a flyer telling him to buy land in Palestine, to which he replies "Nothing doing. Still an idea behind it." (60) But we know that Bloom does buy the kidney and images of Palestine recur throughout the text.

However, the importance of narrative in this instance, lies in its ability to be part of Bloom's actual thought process and part of the narrator's information for the reader. Not only is information transmitted to the reader, but a sense of the dichotomy of emotions and activities of living in a place that is not "yours." Joyce demonstrates the layers of emotional and societal control placed by the dominant culture or by personal mores. Through a layered look at a few moments with Bloom, Joyce comments on social, cultural, and personal aspects of Bloom's life. Narratives are developed through a multilayered technique. More importantly, it offers 12 
more than just dialogue by suggesting the underlying cultural reality of a society. The implications of multiple representations of reality are limitless, polyphonic. Here, Bloom is unleashing any energy by rejecting the land in Palestine and buying the kidney; he is beginning to break away from the social hierarchy which would have controlled his life. This destruction of hierarchical laws is a principle element in carnival and literary carnivalization.

In Hugh Kenner's discussion of the Circe episode in

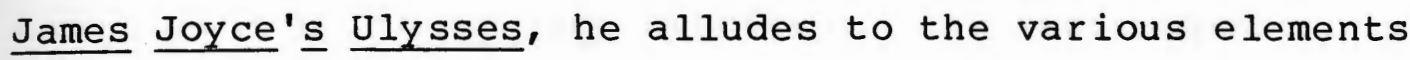
of carnivalization without ever realizing that he was discussing a major literáry structure evident throughout all ulysses, not found solely in Circe. For example, Joyce has little sense of the past, and never sets his imagination yearning after its echoing otherness. He takes great pleasure in grotesque present efforts to recreate the past.. . (Hart and Hayman, 345)

From Circe, Kenner quotes,

The Mabbot street entrance of Nighttown, before which stretches an uncobbled tramsiding set with skeleton tracks, red and green will-o'-the wisps and danger signals. Rows of 13 
flimsy house with gaping doors. Rare lamps with faint rainbow fans. Round Rabaiotti's halted ice gondola stunted men and women squabble. . . (Ibid., 346)

He then proceeds to explicate this passage:

This is surely 'selected' and 'arranged' to the point of Gothic parody; . . . [t]hey do not know by the way that they are serving to express Halloween grotesquerie . . And as Ulysses is the Odyssey transposed and rearranged, 'Circe' is Ulysses transposed and rearranged (Ibid., 356).

Kenner uses the vocabulary of literary carnivalization and he touches upon some carnivalesque concepts such as "otherness," "parody," and "grotesquerie". He does not, however, bring together the conclusion that the other, the parody, and the grotesque are elements which help to subvert reality, to destroy the social monologic hierarchy, and which are the very basis for the fun of literary carnivalization. Unfortunately, Kenner looks upon these elements as negative and detracting from the text, but it is my aim to show that literary carnivalization is yet another means to expand the discussion of Ulysses. 
When discussing the reasons as to why they rejected a formalist approach to the novel, Medvedev and Bakhtin replied that the formalists ". . separate the work from both reality of social intercourse and the thematic mastering of reality. They make the genre the fortuitous combination of chance devices." (Medvedev and Bakhtin, $1978,135)$ The construction of a novel is not left to chance; there must be a greater directing focus or power behind the text.

The categories of carnivalization merge in the single idea of the destruction of social hierarchies. Bakhtin writes that "[a]11 distance between people is suspended, and a special carnival category goes into effect: free and familiar contact among people." (Bakhtin, 1984, 123) ${ }^{2}$ Consequently, all categories involve an interaction between people, their language, and their ideas. Joyce illustrates this interaction as the coming together of diverse elements, beliefs, ideas, and methods of communication within any given individual who happens to reside in a given society. Lyotard calls these systems of communication master narratives--"cannonical narratives" of socialism, Christianity, capitalism, and of the family, law, medicine, and so on. 
The inclusion of master narratives, a variety of common dialogues, gossip, talk, inner voice, babble, and narration for example, is the polyphonic novel. Bakhtin writes that polyphony is a compositional principle--the unification of highly heterogeneous and incompatible material linked with the plurality of consciousness centers not reduced to a single ideological common denominator. (Bakhtin, 1984, 17)

Part 2: Textual Analysis

I. Elements of Literary Carnivalization.

\section{PARODY}

Parody, the first of five aspects in the carnivalization of literature is a regenerative process with seemingly boundless space for its subtleties. The element of parody is injected into the texture of the writing in such a manner that that the reader is confronted with variations which he is tempted to take for the norm, which in its turn is inevitably subverted by that hesitation between origins. The text . . becomes a place where the author 16 
pits discourses against one another, always distorting them slightly. (Topia, 1984, 104)

Joyce's use of parody is revolutionary not because it is included in the text, but that the end result of the parody is the object on which to focus. In Ulysses, the emphasis of parody has shifted from the original "object" being parodied, to the result of the parody; this formula offers variations or copies of old themes which have been reworked to the point of being cliché. Joyce's parody subverts the original form that was previously conceived as the dominant form.

In Ulysses, parody is understood best when it is considered to be a "parody-in-difference," a reproduction of the original which we know to be a copy, a facsimile, the "other" as the "same." Throughout the text, the reader encounters examples of parodies on the age of the modern, the age of the mechanical--on reproductions themselves. Parody calls into question everything about the notion of mimesis connecting the art of Homer with the art of Joyce.

In order to understand Ulysses as truly polyphonous and parodic, the old formalist mantle of Homeric parallel must be reexamined. Releasing ulysses from the limitations of this structural bond enables readers to move more freely throughout the text, examining the 17 
various elements comprising literary carnivalization. If we view Ulysses as a parody of Homer, the results will not be a static reading but rather a detailed view of how a society creates its own narratives and myths, and conversely how myths and narratives help to form a society through the continual process of story-telling.

Ulysses is a mock epic. As Ulysses wandered for years in an attempt to reach his wife, so too does Bloom wander the day away, finally reaching his wife. However, our hero does not have the characteristics that Homer's had: Bloom is not very handsome for example, nor does he have divine intervention in his life. Rather than parallels, Joyce highlights the differences. Joyce did not create a serious representation, but a parodical adventure through a new use of language, representations of discourses, and the incorporation of modern techniques and themes into an ancient classic.

A parody of the Odyssey, set in Dublin, in 1904, will offer a closer view of Edwardian life in a large city, communication, master narratives, but most importantly, a parody of Homer's work will begin to develop new possibilities for fiction, and it will aid in the reshaping of reader expectations of fiction--"limitations" or rather, its limitlessness. Whereas Homer was 
reproducing societal hierarchies for his audience, Joyce reproduces Homer while subverting the hierarchies which Homer had constructed and validated.

The conceptual framework for the text incorporates various elements of Dublin life held to close scrutiny through parodical means. Stylistically, the creative force of some chapters demonstrates the ease by which parody is worked through a text. Although the first chapters begin with traditional techniques, narration or monologue, Joyce, in the Aeolus episode, parodies a 1904 communication system: journalistic reportage based on newspaper sections and features.

A city's lifeblood surges from its ability to deliver information pertinent for its citizens; this is done chiefly through newspaper circulation. In Aeolus, Joyce offers a montage of headlines not of actual newsworthy events, but bizarre headlines bluntly describing Bloom's activity. The headlines, however, are metonyms for activity outside of the text: for the actual craft of writing, "copyrighting," "copywriting," and also for fine writing. The parody in this episode is the parody of mass communication. 
All action, and in some cases the actual work, is introduced through headlines representative of the activity or the information, for example, ORTHOGRAPHICAL, with a brief discussion of the work project. "Want to be sure of his spelling. Proof fever." (121) Not only are the matters of publishing a newspaper illustrated, but also daily activities. For example, the headlines also keep the reader aware of Bloom's activity, his comings and goings from the office:

\section{EXIT BLOOM}

--I'm just running around to Bachelor's walk,

Mr Bloom said, about this ad of Keyes's. Want to fix it up. They tell me he's round here in Dillon's. (129)

Although the reader is offered access to Bloom's place of employment and the headlines depict newspaper articles, the reader remains hard pressed to locate any "real" news; the information offered is not what is expected to be seen in a newspaper.

0 , HARP EOLIAN

He took a reel of dental floss from his waistcoat pocket and, breaking off a piece, twanged it smartly between two and two of his resonant unwashed teeth. (127) 
--Will you tell him he can kiss my arse? (146)

\section{WHAT?--AND LIKEWISE--WHERE?}

--But what do you call it? Myles Crawford asked. Where did they get the plums? (149)

Joyce forces readers to reconceive their assumptions about the transference of information and the abilities of any text, fictive or factual, to represent action through methods not aligned with monologic discourse. As narratives position the addressee, the changes in what is inscribed by the community is illustrated. The insignificant is shown to be grandiose, as reflected in the bizarre headlines.

Joyce's parody of the newspaper not only defies the reader's perception of what a newspaper carries, reveals, and circulates, but it also destroys traditional notions of how facts (information) are transmitted within a text. With Joyce, the reader can assume that the destabilization of everything is possible in a modern narrative. 
Carnivalistic parody allows Joyce free reign over the contents and form of his text, recreating new abilities in content development, while at the same time challenging an audience's perception of narration and fiction. As Joyce moves through styles representational of the character's activity or of the events in the novel, he deliberately creates a multi-voiced narrative--a polyphonous work while demonstrating that a novel can be represented in ways not aligned with the traditional monologic text. The stylistic variations of Ulysses are the very cliches and narrative fragments from society which form the dialogic layering of the text itself.

Joyce's methods for secession from traditional fictive modes of representation are not limited to a parody of communication systems; episode thirteen of Ulysses (Nausicaä) parodies literary styles common to pulp novels and romance magazines of the time. As Bloom's activity was chronicled in the Aeolus episode through his occupation, Gerty MacDowell's thoughts and bourgeois fantasies are the text for Nausicaä. The episode begins thus:

The summer evening had begun to fold the world in its mysterious embrace. Far away in the west the sun was setting and the last glow of all too 22 
fleeting day lingered lovingly on sea and strand . . (346)

The language and diction are presented as Gerty's, but illustrate the layering of communication within society as well as demonstrating people's use of narratives (discourse) for self-definition. It would be impossible for a person to live in a community without absorbing some of that particular society's method of self definition because as Lyotard states:

A self does not amount to much but no self is an island; each exists in a fabric of relations that is now more complex and mobile than ever before. Young or old, man or woman, rich or poor, a person is always located at 'nodal points' of specific communication circuits, however tiny these may be. (Lyotard, 1984, 15) Gerty exists as a 'nodal point.' of the popular culture. Although Naúsicaä may appear to be a traditional narration, it is actually a highly stylized parody of Dublin's popular culture through the parodical use of stylized voices from systems of communication: romance magazines and pulp novels. Gerty's "voice" is non-existent, but she is defined through this limiting dialogue representing a popular pastime for some people in 
Dublin; she is indirectly characterized as dialogical--part of her culture while being the mouthpiece for the culture. Her consciousness is derived from the culture itself. Her own thoughts are displayed through the vocabulary and style of a cheap romance novel as she fantasizes about Bloom. "Then maybe he would embrace her gently, like a real man, crushing her soft body to him, and love her, his ownest girlie, for herself alone." (358)

About Gerty in Nausicaä, Fritz Senn writes:

We are also treated to a close-up of Gerty's mind and, simultaneously, are made aware of the forces that helped to shape it. . . In one way, Gerty is indistinguishable from the forces that determine her. That through such a melange of set pieces and trash, she does emerge as a person in her own right, however limited, is a triumph of indirect characterization. (Hart and Hayman, 309-310)

Through parody, Joyce highlights an alternate means of self-definition in a modern society. Bloom defines himself through actions and occupations while Gerty internalizes the popular culture and becomes its representative. The narration of the episode mimics self-definition through society: Gerty is described 
through definitions set by the current system transmitting definitions of "vogue." The episodic narration illuminates Gerty's dependency on these magazines for her personal self-definition and consequently, Gerty is a parody of society. She is a combination of the cultural forms surrounding her. Rather than Gerty working toward a better Dublin, Dublin is defining Gerty through the popular discourse of the day. Gerty is not the only female in Dublin to experience this self-definition through pulp fiction, but rather she is the representation of many other women. The chapter itself is drawn so as to demonstrate the parodies of pulp fiction and the consequence of those women "who read too much" and develop bases for fantasies. The parodic basis in Nausicaa is multifold as the Nausicaä point of view is actually doubles for both the narrator and for Gerty. The point of view also parodies the act of narration itself, thus constituting a very ironic mode of representation.

Oxen of the Sun is structured as a history of language. In this chapter, language is paralleled to the growth and development of a baby, but parody is the device of the chapter, revealing cliché as society's ultimate narrational form. Parody is the device used to demonstrate language's evolution and to chronicle both 
biological and social evolution. Language is made parallel to the growth and development of Mina's baby and occidental culture and to the Irish culture. A generation ago, Gilbert noted the purpose to this episode: "[t]he technic and the subject of the episode are both embryonic development and the styles of the prose employed follow an exact historical order." (Gilbert, 1958, 296) Gilbert writes that the chapter "begins with a set of incantations." Incantations have generally been performed orally and the history of language itself is based upon an oral tradition of story-telling, knowledge passed down orally rather than through a written text. The chapter opens with the oldest form of communication: people's culturally laden speech. As the chapter (and the baby) develops, language and writing from later periods are represented.

Universally that person's acumen is esteemed very little perceptive concerning whatsoever matters are being held as most profitable by mortals . . (383)

Gilbert characterizes this portion as "written in medieval Latin." (Gilbert, 1958, 298) Doubtlessly, this quotation is reminiscent of the history of our language; but subsequently, as society develops, thus does its language. 
During the development of language--literary, theological as well as chronological--time is passing. In a scene reminiscent of Christian's "good Friday" before Easter, and invoking the memory of Jesus' followers, Ireland is called upon.

Remember, Erin, thy generations and thy days of old how settledst little by me and by my word and broughtest in a stranger to my gates to commit fornication in my sight and to wax and kick like Jeshurum. - Look forth now, my people, upon the land behest, even from Horeb and from Nebo and from Pisgah and from the Horns of Hatten unto a land flowing with milk and money. (393)

This quotation is characteristic of the King James version of the Bible, seventeenth century, because not until after this is Blake parodied in the text. "But the braggart and boaster cried that an old Nobodaddy was in his cups it was muchwhat indifferent and he would not lag behind his lead." (395) What is being established is the decline of the supremacy of the church and the breakdown of the church's power to control the perceptions of its followers. As in a carnivalized novel, the eventual breakdown of authority occurs. 
By the end of the chapter the language, like the baby, has come full term into the "modern" with the image of the carnival barker or sidewalk preacher discussing the image of god: "The Deity ain't no nickel and dime bumshow." (428) Colloquial expressions such as "ain't" and "nickel and dime bumshow" and the comic image of the barker representing religion is Joyce's affirmation of all language. More importantly, the breakdown of the language of the church--or of a religious body--demonstrates the breakdown of the power and the role of the church in a modern society. Joyce has presented the "other" using a known master narrative through a traditional carnivalistic strategy--parody. Moreover, parody of language itself offers visual proof of polyphony in texts as well as in society through the demonstration of varied abilities and results of communication and its representations. The narrational apparatus is built on the multiplicity of storytelling devices such as polyvocality, which signal the nuances of the cultural development of language as it illustrates society's evolution. Oxen of the sun represents the growing polyglot democratization of language, as would be expected in a carnivalistic novel. Language is recognized as the chief level which is truly social--accessible to all people, and as such it is the 28 
social bond. By the conclusion of the episode, language has become a conglomeration of all discourse, dialogue combined with heterogeneous elements illustrating the varied structural layers of communication.

\section{PROFANATION}

The second characteristic of the carnivalization of literature is profanation, defined by Bakhtin as: carnivalistic blasphemies, a whole system of carnivalistic debasings and bringings down to earth, carnivalistic obscenities linked with the reproductive power of the earth and the body, carnivalistic parodies on sacred texts and sayings, etc. (Bakhtin, 1984, 123)

With the use of profanations is the ever present transgression of any social hierarchies, and for Joyce, this was pertinent especially to religion, which he considered to be a monologic discourse. Religion, in which dialogue is never requested or sanctioned, is the principle butt of profanations in Ulysses.

The first images and words spoken in Ulysses are a profanation of a Christian Eucharistic ceremony: 
Stately, plump Buck Mulligan came from the stairhead, bearing a bowl of lather on which a mirror and a razor lay crossed. A yellow dressinggown, ungirdled, was stained gently behind him by the mild morning air. He held the bowl aloft and intoned: "Introibo ad altare Dei." (2-3) As Stanley Sultan reminds us, these are "the first words spoken in the introit to the Catholic Mass." (Sultan, 70) Ironically, the introit will resurface during the black mass in the Circe episode, but in amended form. From the beginning of the text, the reader is alerted to the fact that the Dubliners rejoice in their profane dialogues and they continually use whatever method that may be at their disposal to subvert and destroy the power of the church. Nothing will be beyond examination and profanation, and both Buck Mulligan and Stephen Dedalus will be the greatest perpetrators throughout the text.

In the opening pages of the text, one of the master narratives of the Irish community, the Christian fable, is set up for ridicule by Buck Mulligan in his recital of "The ballad of Joking Jesus." 
--If anyone thinks that I amn't divine

He'll get no free drinks when I'm making the wine But have to drink water and wish it were plain That I make when the wine becomes water again. This is only one stanza from a three stanza song, but it clearly illustrates Bakhtin's definition: the debasing of a sacred text. The use of the Bible as the basis for a humorous song appears to be sacrilegious to some readers of Joyce, but a major factor in the carnivalization of literature is the destruction of any type of barrier that exists between people. Religion and the subsequent nationalism placed unnecessary restrictions on the Irish, and consequently, religion has become a limiting force in society rather than serving as an aid to people.

The ballad of Joking Jesus appears again in the Circe episode with an additional stanza sung by Edward the Seventh:

My methods are new and are causing surprise. To make the blind see I throw dust in their eyes. (591)

As in the Oxen of the Sun episode, carnival establishes "the other" against the devoutly religious citizens of Dublin. With Buck Mulligan, as well as Stephen Dedalus himself, Circe offers a variety of persons 
and their profane actions indicating a polyphonic representation of what constitutes the line between profane and religious expression.

Stephen Dedalus's humour is not only satirical and sharp, but it is also profane. The secularization of religious imagery latent in Stephen's verbal attacks directly opposes a patriarchal society and Catholicism, specifically. Stephen is fighting against the hierarchy and social stratification inherent in religion by using intertextual quips and parodies of religious texts as a basis for his humor. In order to achieve his goal, nothing is too sacred. For instance, in the Nighttown episode, Stephen parodies the beatitudes with a list of his friends: "The beatitudes, Dixon, Madden, Crotthers, Costello, Lenehan, Bannon, Mulligan, and Lynch i.n white surgical student's gowns, four abreast, goosestepping, tramp fast past in noisy marching.". (509) Stephen calls on Dublin's "finest youths" to represent The Beatitudes. A known entity from the Gospels is rerepresented in ways not aligned with traditional definition; stephen is offering his friends in fulfillment of the words. To Stephen, the Beatitudes are only words, consequently, anything could have been (and was) substituted in their place. 
This debunking of traditional religious associations holds the church in closer scrutiny for society--the teachings can no longer be accepted passively; Stephen'snew associations have been made and cannot be forgotten. Profanations, for Stephen, bring religion back to its earthly beginnings--a tool for the people, and for stephen, it has become a tool for humor. As a quick aside, Stephen exclaims "Lamb of London, who takest away the sins of the world." (560) Here, Stephen is offering another voice, another perception of the liturgy, and developing a pastiche wherein the original text no longer has the same meaning or strength. Stephen has subverted the text verbally. The text can never be returned to the state in which it existed prior to the profanation because the new signification can never be erased from the memory of everyone who has heard. The polyphony stephen has created helps to destroy the hierarchical power structure found in organized religion.

Along the same vein of profane significations of actions are episodes which do not enhance the plot, nor do they effect change in people's perceptions of religion, but they do allude to the lessening power that religion has over its people. For example, in Lotus-Eaters, Bloom thinks about Catholicism and as he watches a priest, he 
contemplates the initials I.N.R.I and remembers a quip which Molly had told him: "Iron nails ran in." (81) Yet another episode involving irreverent occurrences takes place in the Circe episode, as "The very reverend Canon o'Hanlon in cloth of gold cope elevates and exposes a marble timepiece. Before him Father conroy and the reverend John Hughes S.J. bend low." (469) These are profanations of sacred words and actions which demonstrate not only the carnivalistic destruction of authorial control, but also begin to demonstrate for the reader that nothing remains sacred forever. Moreover, in terms of a social history of the Irish, these satires indicate the inadequacy and falsity of the monologic religious voice.

An extended profanation is the parody of the holy mass into a black mass also found in the Nighttown episode. Distant voices tell that Dublin is burning and immediately the scene shifts to the black mass characterized by witches, whores, thieves, and the dead of Dublin all participating in this diabolical image once again indicating the destruction of barriers between the perception of good and evil, also between life and death. Carnivalization encourages the ultimate breakdown of polarities and of the norms restricting realism of the body as is seen in the image of the sacrifice. The 34 
Eucharistic sacrifice made in a Catholic mass is delivered its "other" in the black mass as Father Malachi O'Flynn says the first words of the mass "Introibo ad altare diaboli" (599) and as the text itself began with a profane version of the Catholic Mass, the Black Mass is now a blatant invocation to the devil thus developing the carnival idea of the destruction and reversal.

\section{DUALISMS}

Parallel with the Oxen of the Sun episode is the woman as sacrifice during the Black Mass in Circe: "On the altar stone Mrs Mina Purefoy, goddess of unreason, lies naked, fettered, a chalice resting on her swollen belly." (599) In this vision of sacrifice and death is also the image of life. Mina Purefoy gave birth to the baby in the oxen episode. The dualism of death and renewal represents the third aspect of carnivalization.

The image of death/renewal is a clue to duality inherent in every part of carnival life. Dualisms are not created to offer choices, rather they offer a dichotomy, a simultaneous schema of two seemingly opposing images or facts. The characters themselves are the best example of the duality inherent in every structure. For example, 
Gerty MacDowell, a young girl, is a clear example of the Virgin/ Whore debate. As was already demonstrated, the reader knows Gerty's feelings toward Bloom. Later in the Nausicaa episode, Gerty teases, seduces, Bloom during the fireworks: "he had a full view high above her knee no-one ever not even on the swing or wading and she wasn't ashamed and he wasn't either. . . " (366)

Is Gerty a flirt or is she just experimenting with new feelings? In the Nighttown episode Gerty appears, but her amount of participation is also unclear. Although Gerty appears in the midst of a discussion about prostitutes, and she says to Bloom, "When you saw all the secrets of my bottom drawer. . . Dirty married man! I love you for doing that to me" (442), the secrets that she mentions and exactly what Bloom "did to her" are not revealed. Bloom may be projecting his thoughts and perceptions onto a representation of Gerty. The readers have seen her as a flirtatious, but definitely not a whorish girl; if anything, she is merely a (self)construction of her society's romantic literature.

The virgin/ whore syndrome is an example of the dualism that carnivalization can bring out in literature. Everything is replaceable; Gerty can be a normal child and then instantaneously changed through someone else's 
perceptions. In carnivalization nothing is static or finite; "the other," the ever-changing is the important feature.

The Leopold Bloom/ Henry Flower dualism functions not necessarily to further the plotline but to offer multiple sides of Bloom simultaneously. At any moment Bloom can become Henry Flower. The instability of facts makes the carnival an exciting experience. Bloom's entire personality is captured in this dualism. For instance, in the Nighttown episode, Bloom, engaged in a dialogue with Virag, is taken over by Henry (Flower, presumably). Bloom's personality, his persona itself, has been destabilized by this alter-ego. The names are a direct pun, and the person, to whom Bloom is speaking is Virag, a name derived from the Hungarian word "Virago" meaning Flower. Moreover, in English, Virag, Bloom's father's original surname, means a manish woman; also in the Nighttown episode, $\mathrm{Dr}$ Dixon refers to Bloom as "the new womanly man." (493) This duality leads into the reversal of personalities for Bloom, foreshadowing his sexual transformation later in the Nighttown episode. 


\section{REVERSALS}

LaCapra writes that "reversals effect • . a generalized displacement of ordinary assumptions." (LaCapra, 1985, 299) Reversals may also pose a: threat to hierarchy and direction . . [e] ach inversion and reverse undercuts the status of the original order. • . [i]nversions - call status and role relationships into question, and linguistically inversions emphasize the reversible and flexible nature of communication. (Stewart, 1979, 68/9)

Characteristic of reversals is the destabilization of identity through the idea of carnival masks. Nothing is static or as it necessarily appears, once again, "the other" is offered as an extension of reality creating a dialogic layering of technique and result, in order to destabilize ordinary perceptions of reality. Bella/ Bello, the madam of the brothel in the Nighttown episode, and the Man in the Macintosh, as the literary equivalent of a carnival mask for Joyce himself, are two excellent examples of reversals in Ulysses. The destabilization of identity subverts Ulysses though the very thing which creates it--language. The world offered by Joyce is at anytime inverted and consequently creates a new set of 
rules/images for society. There are no boundaries oncreativity or self-expression; nothing is bound by traditional definition of time, matter, or space.

The Bella/Bello example is subtle because not only does the Madam change sex, but so does Bloom. The duality of Bloom's personality runs throughout the text, but is not blatantly perceptible until the Nighttown section. No longer can assumptions/definitions about a person be based on sex. The role reversals for Bloom and Bella indicates not only the abilities of carnivalized literature, but the destruction of definitions of "masculine" or "feminine" which may have been used to define a person. As LaCapra has indicated, nothing can be assumed in any situation--bodies change sexes and inanimate objects are given the power of speech. Reversals not only indicate the elimination of hierarchies among bodies, but reversals also allow the text to add what was previously considered the supernatural to the realism of the corpus itself. Reversals destroy any limitations on a text--reversals set everything in opposition to itself resulting in the breakdown of polarities, and also destabilize requirements for fiction.

Bella, the madam, meets Bloom. The first indication that something is strange is the switch in pronouns attributed to Bloom: "Her eyes upturned . . she 
sinks. . " and immediately after the language used to represent Bloom is changed Bella becomes Bello. (531) The change in sexes of the two characters also allows for a sado-masochistic portrayal of sexual activities to develop. Bloom becomes Bella's slave: "What you longed for has come to pass. Henceforth you are unmanned and mine in earnest, a thing under the yoke." (535) Eventually Bloom does return to his male identity and Bello becomes Bella once again. However, the transfiguration of Bloom is continuously portrayed throughout the novel.

About reversals in the carnivalization of literature, Bakhtin writes, "men are transvested as women and vice versa . . ." (Bakhtin, 1968, 411) For example, Bloom's erratic sexual states are prefigured in a multitude of episodes. For example, Bloom's full name is Leopold Paula Bloom (723) indicating androgyny and the possibilities for various sexual identities. In the Nighttown episode, subsequent to his transformation with Bella, Bloom physically has children: "Bloom embraces her tightly and bears eight yellow and white children." (494) Toward the end of the text, Bloom's identity is characterized as "Everyman or Noman." (727) The inability to define Bloom sexually or through gender is a common trait of reversal in carnivalization. It also represents the removal of 40 
norms restricting the expression of the realism of the body as will be developed in fuller detail in the last portion of the definition of carnivalization.

A question bothering Joyce scholars has been the identity of the man in the macintosh appearing throughout the text. Some of the masks employed by those participating in the carnivalesque are traditionally the clown, the jester, or the fool "and are the envoys of carnival in everyday life, and the novelist dons the masks in modern society." (LaCapra, 1985, 301) Masks, although literary, are a vehicle for Joyce to swap places with his characters.

The man in the macintosh does not participate in action that alters the events of the novel; he simply exists as a recurring image. There are three separate incidents wherein the man in the macintosh appears. Each has to do with some kind of authorial power, or a knowledge or ability greater than that of the characters.

The first time The Man is connected with any events of the text is in episode six, Hades, in a graveyard. As Bloom counts the number of mourners, "[t]he chap in the macintosh is thirteen. Death's number." (110) MY hypothesis concerning The Man is that he is the carnivalistic mask for Joyce himself. If The Man is 41 
number thirteen, attributed to death, possibly it could be a dualistic representation of death/renewal. The Man could be a representative of authorial control so that we the readers never forget who the guiding force of the text actually is.

In Paddy Dignam's obituary, the mourners are listed. The man in the Macintosh is now know as M'Intosh and his name is set off by a hyphen. (647) The hyphen has no other purpoșe but to call attention to the name M'Intosh. In a small community such as Bloom's, people seem to know each other (and their respective families) very well. Bloom not being acquainted with M'Intosh is highly unusual. Later in the text, Bloom is said to have never "comprehended the enigma of M'Intosh." (729) Although there is no clear explanation for the identity of this character, the carnivalistic ploy of a mask would help to solve this dilemma. The man in the macintosh is a representation of Joyce who just could not help to immortalize himself as both author and character. Or, the Man in the Macintosh could also represent the reader, our Own access to the actual happenings in Dublin, 1904. If he were a figure representing the reader, The Man would represent dialogic excess between us and Joyce. No matter if we choose the author/character scenario, or the 
character/reader scenario, then The Man remains larger than the bounds of the text itself. This reversal of roles is a prime example of the limitless abilities of a carnivalized novel.

\section{GROTESQUE REALISM}

The fifth and final section to the definition of the carnivalization of literature is that of grotesque realism or the grotesque aesthetic. Grotesque realism is an extended parody of food and the body. Bakhtin characterizes it as "carnival and culinary anatomy." (Bakhtin, 1968, 196)

In grotesque realism . . the bodily element is deeply positive. It is presented . . as something universal, representing all people. - The material bodily principle is contained not in the biological individual . . but in the people. . . The leading themes of these images of bodily life are fertility, growth, and a brimming-over abundance. The essential principle of grotesque realism is degradation; . . it is a transfer 
to the material level, to the sphere of earth and body. . . Degradation here means coming down to earth . . the life of the belly and the reproductive organs; it therefore relates to acts of defecation and copulation, conception, pregnancy, and birth. (Bakhtin, 1968, 19-21)

If the carnivalization of literature is the elimination of barriers between people and classes of people, the most important work in recognizing our humanity, between all the levels and groups, is that which incorporates the body as the ultimate metaphor for our shared humanity. Although Joyce creates a linguistic experiment in Ulysses, he also creates a tribute to the body through the use of carnivalistic grotesque realism.

The imagery of Bloom and Molly, especially, throughout the text is that of the earthly and real, without a facade to separate them from other people. Although examples may be taken from other works of literature, such as Don Quixote, which praise elements of grotesque realism, none other than Ulysses is such a monument to the body. Unlike other parts of the definition of carnivalized literature, the main focus of the section is already a polyphonous object prior to its textual representation and 
incorporation. The body is a polyphonous object: it thinks, smells, eats, loves, has a memory; it functions independently, without need for prompts to motivate it. In and of itself, the inclusion of the body in a novel begins to define the polyphony in Ulysses.

The combined images of food/body are frequent throughout the text. When Bloom is in Dlugacz's buying his lamb kidney, the imagery for both males and females contains descriptions of food. The butcher had "blotchy fingers, sausagepink" and as Bloom leaves, he follows a woman out of the store and walks "behind her moving hams." (59) When Bloom is in the church watching the mass, he contemplates the idea of the Eucharist: "What? Corpus. Body. Corpse . . eating bits of a corpse why the cannibals cotton to it." (80) And at Paddy Dignam's funeral he thinks about the smell of a corpse: "They wouldn't care about the smell of it. Saltwhite crumbling mush of corpse: smell, taste like raw white turnips." Bloom also asks "What's cheese? Corpse of milk." (114) Grotesque imagery is dialogic as well as carnivalistic, it combines elements of daily life in ways that would not ordinarily be expressed. 
Bloom is the personification of food and bodily functions. From the moment we meet him, Bloom is eating. "Leopold Bloom ate with relish the inner organs of beasts and fowls. - . Kidneys were in his mind as he moved about the kitchen. . . " (55) Bloom is immediately depicted as a physical person, one in touch with his senses and bodily desires. For the major part of the text, Bloom's bodily functions and desires rule his activity. Ulysses is unique in that it is one of the first works wherein the reader experiences a character's time in the W.C.

Midway, his last resistance yielding, he allowed $h$ is bowels to ease themselves quietly as he read . . that slight constipation of yesterday quite gone. (69)

The description of bodily functions or parts, and the description of sexual activity and feelings is less to scandalize and to shock and more to exhibit and examine as signification the physical. Again the purpose would seem to be the disclosure of otherness, bringing it into signification. The readers get to know Bloom like few characters are ever known. We are present as he eats, defecates, urinates, and even masturbates as he watches Gerty while she watches the fireworks. Through an 
extended metaphor of fireworks and Roman candles, the audience becomes aware of Bloom's actions:

And then the rocket sprang and bang shot blind and 0 ! then the Roman candle burst and it was like a sigh of 0 ! and everyone cried $0 ! \cdot$. . O so soft, sweet, soft. (366-67)

and also his reactions:

Mr Bloom with careful hand recomposed his wet shirt. O Lord, that little limping devil. Begins to feel cold and clammy. Aftereffect not pleasant. Still you have to get rid of it someway. (370) Bloom makes the entire incident seem like an everyday occurrence for him. The body has become a symbol of all that is natural and of the earth. The connection between the earth and sexuality is found repeatedly throughout the text. Not only do readers become voyeurs as Bloom masturbates as HE watches Gerty, but they also know he masturbated while watching Lotty Clark. "I was precocious. Youth. The fauns. I sacrificed to the god of the forest. The flowers that bloom in the spring. It was pairing time. . . I saw at her night toilette through illclosed curtains, with poor papa's operaglasses. (549) For Bloom there is nothing indecent about his activity. This feeling of naturalness is also displayed in Molly's 
character. She is a woman who knows her body, how to use her body, and knows what gives her pleasure from her body. While Molly has been characterized as the great Earth mother, some feminists dislike the "stereotypical" maternity she also represents. These critics, Toril Moi argues,

have objected to Joyce's portrayal of Molly Bloom's chamberpot and menstrual cycle . . on the grounds that, in spite of their undeniable realism, these factors contribute precisely to presenting her as a biologically determined, earthbound creature that no woman reader can really admire. (Moi, 1986, 47)

However Molly is the quintessential carnivalistic character, she represents nearly all the elements of carnival in a combination of sex and sensuality. She eats, sleeps, has sex; and takes care of her bodily functions. Molly is the personification of the body and polyphony and moreover, the carnivalized character.

The individual elements of carnival conjoin within her one person. The fact that Molly's episode is a printed version of an interior monologue reverts backs to the discussion about the limitations of traditional fiction, and the Penelope episode reinforces the excesses of the 48 
carnivalized text and its varied possibilities.

Fur thermore, Molly asks Joyce directly to be removed from her function in the text "O Jamesy let me up out of this pooh" (769) and demonstrates the excesses between creator and character as with the Man in the Macintosh.

Elements such as grotesque realism repeatedly occur within the confines of her character. For example, "yes I think he made them a bit firmer sucking them like that so long he made me thirsty titties he calls them" (753) and examples of profanation can also be found. Molly contemplates being with a priest: Id like to be embraced by one in his vestments and the smell of incense off him like the pope..." (741) Molly is a complex creation, more so than may critics have noted.

In Male Novelists and Their Female Voices, Taylor makes assumptions about Molly's character: her language, thoughts, and body. Although Taylor focuses on Molly's carnivalistic features, the assumptions drawn are both unlikely and naive.

Just as the modern Ulysses and the modern Telemachus have fallen from heroic status, the modern Penelope is awash in men, food, stockings, gloves, religion, sex--the most sacred and profane are conjoined. Her mind 
is a garbage dump. (Taylor, 1981, 205)

Taylor's linkage between the sacred and the profane as carnivalistic characterizations illustrates the beginnings of the list of themes without resolution in Taylor's own textual exposition; however, to conclude that Molly's "mind is a garbage dump" is not only groundless but unproductive because it draws no tangible conclusions; it is a gross generalization. Fur thermore, Taylor continues to circle the carnivalistic components without drawing a valid conclusion. While examining Molly's speech Taylor writes:

She seems overwhelmingly grotesque. . . [t]here are no boundaries between anyone or anything in this monologue, between me and not me, he she, or it. Supposed to be the tapestry of the weaver Penelope, it seems a form of madness, a woman's tongue loosed upon the world of night. . . Molly is a "grotesque portrait of flesh incarnate. (Taylor, 1981, 206-207) Molly's "tapestry" is not madness but the conglomeration of carnivalistic elements: sacred/profane, grotesque, and the elimination of boundaries between people. Molly's position at the end of the text clearly defines her as the epitome of the carnivalesque character. Throughout the 
text, the individual elements of literary carnivalization have been utilized by Joyce; however, not until the Penelope episode do all the elements come together in a single character--that of Molly Bloom.

Taylor also brings the definition of polyphony to a new "text." Taylor "houses" the various characteristics in Molly's body without ever defining the polyphonous role of body, a polyphonous entity combining thoughts, emotion, language, the five senses, memory, and so on. The conjoining of carnivalistic elements in Molly ends the synecdoche which has occurred chapter by chapter, throughout the text. For the first time, the reader is able to see the final product of the carnivalization of literature. After each element was studied individually, Molly emerges as Joyce's triumph.

Molly's affairs with Blazes are no secret from anyone and her naturalness becomes her most compelling feature as she tells the readers of her loves and exploits, comprising Molly's unique self-awareness. One of the recurring images of Molly is of her bottom, either being kissed by Bloom or slapped by Boylan.

He $\mathrm{k}$ issed the plump mellow yellow smellow melons of her rump, on each plump melonous hemisphere, in their mellow yellow fur row . . (734-35) 
Molly's body is an example of the overabundance of material during carnival as is also illustrated through her memories about breastfeeding: ". . I had a great breast of milk with Milly enough for two . . . " (754)

Like Bloom's masturbatory episode, we also hear about Molly's erotic moments: ". . tickling me behind with his finger I was coming for about 5 minutes with my legs round him I had to hug him after . . ." (754) The body is not an image of shame or of something private, to be hidden away; rather, it is the joyous celebration of life, the greatest carnivalistic experience.

As stated above, Bakhtin calls grotesque realism a "carnival and culinary anatomy." Aspects of carnival have been highlighted in this text, but the culinary definitions may also be drawn through Molly Bloom. The carnival feast, food, and the body are intertwined to develop the carnivalistic character.

Eating and drinking are one of the most significant manifestations of the grotesque body - . The encounter of men with the world, which takes place inside the open, biting, rending, chewing mouth, is one of the most ancient, and most important objects of human thought and imagery. Here man tastes the world, 52 
introduces it into his body, makes it a part of himself. (Bakhtin, 1968, 281)

This mingling of body and food is celebrated by both Molly and Bloom as they recall an earlier time in their lives, through the image of seedcake uniting these two bodies.

Ravished over her I lay, full lips open, kissed her mouth. Yum. Softly she gave me in my mouth the seedcake warm and chewed. Mawkish pulp her mouth had mumbled sweet and sour with spittle. Joy: I ate it: Joy. And then Molly's perception of the incident:

- I got him to propose to me yes first I gave him the bit of seedcake out of my mouth - - after that long kiss I near lost my breath yes he said I was a flower of the mountain yes so we are flowers all a womans body yes... (782) •

The profane image of the mingling of body/food, rather than a religious "body/blood Christ imagery," and the merging of the souls (Molly's and Bloom's) with the grotesquely realistic sharing of the seedcake indicates the true interconnectedness of these two people and the unequivocal definition of Ulysses as a carnivalistic text as all the elements merge in Molly Bloom. 
II. Conclusion.

Polyphony in literature is a compositional principle. The composition of a variety of heterogeneous voices, techniques, and their subsequent merger under the heading of "novel" is a polyphonous text. The validity of the merging of seemingly disharmonious elements develops with the structure of the text itself. Bakhtin writes that the "basis for a polyphonic text [1ies] in the objective multileveledness of 1 ife and [the] ability to see the world [as an] interaction and coexistence. (Bakhtin, 1984, 30) The results of the application of the carnivalistic model used to illuminate Ulysses are examples of the "interaction and coexistence of the multileveledness of life." From the analysis of the text through the five-point definition of carnivalization of literature, polyphonic layering is evident.

Polyphony in Ulysses is dialogic, linguistic, and technical. The initial demonstration of parody of an ancient classic establishes the basic framework for the polyphonous text. Subsequent layers such as parodies of social language and new visions of master narratives develop a strong foundation for the crowning achievement of textual carnivalization: the body as the new locus for 54 
the destabilization of identity in an excess of communication. The development of "the other," objects of desire, demonstrate a break from the traditional formalist, homogeneous novel characteristic of the bulk of literature before Joyce's renewed use of the carnivalistic technique destabilizing all perceptions/ definitions. Joyce reinterpreted definitions of communication, inclusive of the novel itself, resulting in a more open and creative text because "carnival images are reborn again and again." (Bakhtin, 1984, 165) Joyce destroyed the notion of a static monologic text and expanded the possibilities for representation of society and its ideological structures. The result of a carnivalized text such as Ulysses is a polyphonous exhibition breaking with tradition and an embrace of the modern. Problems inherent in a polyphonous text such as intertextuality and unlimited examples of discourse, narration, speaking, dialogue, gossip, are not mere stylistic methods within a text, but representations of society's communication and consequently, tools used to illustrate the complexity of communication. 


\section{Bibliography}

Ackroyd, Peter. Notes for a New Culture: Essays on Modernism. NY: Barnes and Noble Books, 1976. Arac, Jonathan. "The Form of Carnival in Lowry's Under the Volcano," PMLA 92 (May 1977): 481-189.

Bakhtin, Mikhail. The Dialogic Imagination: Four Essays.

Ed. Michael Holquist. Trans. Caryl Emerson and Michael Holquist. Austin and London: University of Texas Press, 1981.

--- Problems of Dostoevsky's Poetics. Ed. \& Trans. Caryl Emerson. Minneapolis: University of Minnesota Press, 1984 .

--- Rabelais and His World. Trans. Helene Iswolsky. Cambridge, Massachusetts \& London, England: MIT Press, 1968.

Braham, Peter. "How the Media Report the Race." In Culture, Society, and the Media. Eds. Michael Gurevitch, Tony Bennett, James Curran, and Janet Woollacott. London and New York: Methuen, 1982, pp. 268-286.

Budgeon, Frank. James Joyce and the Making of Ulysses. Bloomington and London: Indiana University Press, 1967. 
Burgess, Anthony. Joyceprick. New York and London:

Harcourt Brace and Jovanovich, 1973.

Clark, Katerina and Michael Holquist. Mikhail Bakhtin.

Cambridge, Massachusetts \& London, England: The

Belknap Press of Harvard University Press, 1984.

Cross, Richard K. Flaubert and Joyce: The Rite of

Fiction. Princeton: Princeton University Press, 1971.

Ellmann, Richard. James Joyce. Oxford: Oxford University Press, 1983.

---. Ulysses on the Liffey. New York: Oxford University Press, 1972.

Fludernik, Monika. "The Dialogic Imagination of Joyce:

Form and Function of Dialogue in Ulysses," Style

20 (1986) : 42-57.

Gifford, Don and Robert J. Seidman. Notes for Joyce: An

Annotation of James Joyce's Ulysses. NY: E. P.

Dutton and Co., Inc., 1974.

Gilbert, Stuart. James Joyce Ulysses. New York: Vintage Books, 1955.

Goldberg, S. L. - The Classical Temper: A Study of James Joyce's Ulysses. NY: Barnes and Nobles, Inc., 1969. 
Greenblatt, Stephen. "Filthy Rites," Daedalus 54 (Summer 1982) : $1-17$.

James Joyce's Ulysses: Critical Essays. Ed. Clive Hart and David Hayman. Berkely and LA: University of California Press, 1974.

Joyce, James. A Portrait of the Artist as a Young Man. Ed Chester G. Anderson. New York: Viking Critical Library, 1985.

---. Ulysses. New York: Vintage Books, 1961.

Kershner, R.B. "The Artist as Text: Dialogism and Incremental Repetition in Joyce's Portrait. ELH 53 (Winter 1986): 881-894.

LaCapra, Dominick. Rethinking Intellectual History:

Texts, Contexts, Language. Ithaca: Cornell University Press, 1985.

Letters of James Joyce. Vol I. Ed. Stuart Gilbert. NY: Viking Press, 1966.

Letters of James Joyce. Vol II \& III. Ed. Richard Ellmann. NY: Viking Press, 1966. Levin, Harry. James Joyce. Connecticut: New Directions, 1960 . 
Lyotard, Jean-François. The Postmodern Condition: A

Report on know ledge. Trans. Geoff Bennington and

Brian Massumi. Minneapolis: University of Minnesota Press, 1984 .

Medvedev, P. N. and Mikhail Bakhtin. The Formal Method in

Literary Scholarship. Trans. Albert Wehrle.

Baltimore: Johns Hopkins University Press, 1978.

Mercier, Viviene. The Irish Comic Tradition. Oxford:

Oxford University Press, 1969.

Michie, Helena. The Flesh Made Word: Female Figures in

Women's Bodies. New York, Oxford: Oxford University Press, 1987.

Moi, Toril. Sexual/Textual Politics: Feminist Literary

Theory. London and New York: Methuen, 1985.

Moseley, Virginia. Joyce and The Bible. Illinois:

Northern Illinois University Press, 1967.

Newcomb, Horace M. "On the Dialogic Aspects of Mass

Communication," Critical studies in Mass

Communication 1 (1984): 34-50.

Noon, S. J., William T., Joyce and Aquinas. Connecticut:

Archon Books, 1970.

On Signs. Ed. Marshall Blonsky. Baltimore: The Johns Hopkins University Press, 1985. 
Raleigh, John Henry. The Chronicle of Leopold and Molly Bloom: Ulysses as Narrative. Berkley, Los Angeles, and London: University of California Press, 1977. Richards, Thomas Karr. "Gerty MacDowell and the Irish Common Reader," ELH 52 (Fall 1985) : 755-776. Schutte, William M. Joyce and Shakespeare. Connecticut: Archon Books, 1971 .

Scott, Bonnie Kime. James Joyce. NJ: Humanities International, Inc., 1987. Stewart, Susan. Nonsense: Aspects of Intertextuality in Folklore and Literature. Baltimore and London: Johns Hopkins University Press, 1979. Sultan, Stanley. The Argument of Ulysses. Ohio: Ohio State University Press, 1964. ---. Eliot, Joyce and Company. New York and Oxford: Oxford University Press, 1987. Taylor, Anne Robinson. Male Novelists and Their Female Voices: Literary Masquerades. Troy, New York: The Whitston Publishing Co., 1987. Thornton, Weldon. Allusions in Ulysses. NY: Simon and Schuster, 1973. 
Todorov, Tzvetan. Mikhail Bakhtin: The Dialogic

Principle. Trans. Wlad Godzich. Minneapolis:

University of Minnesota Press, 1984.

Topia, Andre. "The Matrix and the Echo: Intertextuality

in Ulysses." In Post-Structuralist Joyce: Essays From

the French. Eds. Derek Attridge and Daniel Ferrer.

Cambridge: Cambridge University Press, 1984, pp.

103-125.

Wyatt, Ian. The Rise of the Novel. Berkeley and Los

Angeles: University of California Press, 1967.

Yeager, Patricia S. "Because a Fire Was in My Head:

Eudora Welty and the Dialogic Imagination," PMLA 99

(October 1984): 955-973. 
ENDNOTES

${ }^{1}$ ulysses, ix; all reference to this text will be given parenthetically, without any other citation.

2ulysses, 591. In carnival, the activity usually takes place in a common area belonging to all people. "The marketplace was the center of all that is unofficial; it enjoyed a certain extraterritoriality in a world of official order and official ideology, it always remained 'with the people.'" (Bakhtin, 1968, 153-54) The Nighttown episode takes place in a central meeting location for a heterogeneous group of people--near the brothel. This destabilization of official order is directly manifested through the area, and the action of the text during this episode takes on a new spirit. Nighttown is the place where anything is possible; the mere boundaries of life/death, animate/inanimate are destroyed. It is truly the carnivalistic center of the text. 